\title{
Nitrogen Removal Ability and Characteristics of the Laboratory-Scale Tidal Flow Constructed Wetlands for Treating Ammonium-Nitrogen Contaminated Groundwater
}

\author{
Amit Kumar Maharjan ${ }^{1}$, Kazuhiro Mori ${ }^{2}$ and Tadashi Toyama ${ }^{2, *}$ \\ 1 Integrated Graduate School of Medicine, Engineering and Agricultural Sciences, University of Yamanashi, \\ Yamanashi 400-8511, Japan; g17dea01@yamanashi.ac.jp \\ 2 Graduate Faculty of Interdisciplinary Research, University of Yamanashi, Yamanashi 400-8511, Japan; \\ mori@yamanashi.ac.jp \\ * Correspondence: ttohyama@yamanashi.ac.jp
}

Received: 17 April 2020; Accepted: 3 May 2020; Published: 7 May 2020

\begin{abstract}
Constructed wetlands (CWs) are an effective technology to remove organic compounds and nitrogen $(\mathrm{N})$ from wastewaters and contaminated environmental waters. However, the feasibility of CWs for ammonium-N $\left(\mathrm{NH}_{4}{ }^{+}-\mathrm{N}\right)$-contaminated groundwater treatment is unclear. In this study, zeolite-based laboratory-scale CW was operated as a tidal flow $\mathrm{CW}$ with a cycle consisting of 21-h flooded and 3-h rest, and used to treat $\mathrm{NH}_{4}{ }^{+}-\mathrm{N}\left(30 \mathrm{mg} \mathrm{L}^{-1}\right)$ contaminated groundwater. In addition to $\mathrm{NH}_{4}{ }^{+}-\mathrm{N}$, nitrite $\left(\mathrm{NO}_{2}{ }^{-}-\mathrm{N}\right)$ and nitrate $\left(\mathrm{NO}_{3}{ }^{-}-\mathrm{N}\right)$ were also not detected in the effluents from the tidal flow $\mathrm{CW}$. The $\mathrm{N}$ removal constant remained high for a longer period of time compared to the continuous flow $\mathrm{CW}$. The higher and more sustainable $\mathrm{N}$ removal of the tidal flow $\mathrm{CW}$ was due to the in-situ biological regeneration of zeolite $\mathrm{NH}_{4}{ }^{+}-\mathrm{N}$ adsorption capacity. Vegetation of common reeds in tidal flow zeolite-based CW enhanced nitrification and heterotrophic denitrification activities, and increased the functional genes of nitrification (AOB-amoA and $n \times r A$ ) and denitrification (narG, nirK, nirS, and nosZ) by 2-3 orders of magnitude, compared to $\mathrm{CW}$ without vegetation. The results suggest that the combination of zeolite substrate, tidal flow, and vegetation is key for the highly efficient and sustainable $\mathrm{N}$ removal from $\mathrm{NH}_{4}{ }^{+}-\mathrm{N}$ contaminated groundwater.
\end{abstract}

Keywords: nitrogen removal; $\mathrm{NH}_{4}{ }^{+}-\mathrm{N}$ contaminated groundwater; constructed wetland; tidal flow; zeolite; nitrification; denitrification; biological regeneration

\section{Introduction}

Groundwater is a major source of drinking water supply, with $50 \%$ of drinking water supplies in the world based on groundwater [1]. However, groundwater can often be contaminated with ammonium-nitrogen $\left(\mathrm{NH}_{4}{ }^{+}-\mathrm{N}\right)$. Heavy $\mathrm{NH}_{4}{ }^{+}-\mathrm{N}$ contamination of groundwater has been reported in certain parts of Australia (up to $120 \mathrm{mg} \mathrm{NH}_{4}{ }^{+}-\mathrm{N} \mathrm{L}^{-1}$ ) [2], Vietnam (up to $69.8 \mathrm{mg} \mathrm{NH}_{4}{ }^{+}-\mathrm{N} \mathrm{L}^{-1}$ ) [3], China (up to $10 \mathrm{mg} \mathrm{NH}_{4}{ }^{+}-\mathrm{N} \mathrm{L}^{-1}$ ) [4], Central India (up to $57 \mathrm{mg} \mathrm{NH}_{4}{ }^{+}-\mathrm{N} \mathrm{L}^{-1}$ ) [5], and the Kathmandu Valley of Nepal (up to $57.3 \mathrm{mg} \mathrm{NH}_{4}{ }^{+}-\mathrm{N} \mathrm{L}^{-1}$ ) [6]. Excess $\mathrm{NH}_{4}{ }^{+}-\mathrm{N}$ in groundwater makes it undrinkable due to bad taste and odor, reduces chlorine disinfection, and increases the possibility of pathogenic contamination during water distribution. Hence, reducing $\mathrm{NH}_{4}{ }^{+}-\mathrm{N}$ concentration of the groundwater prior to the conventional treatment and distribution of drinking water is essential.

The in-situ permeable reactive barrier (PRB) has been recognized as an effective technology for removing $\mathrm{NH}_{4}{ }^{+}-\mathrm{N}$ from groundwater $[4,7,8]$. However, it requires large-scale construction and incurs a high initial cost [9]. Hence, alternative $\mathrm{NH}_{4}{ }^{+}-\mathrm{N}$ removal techniques requiring minimum energy 
and low operational/construction cost are needed, particularly in developing countries and small rural communities.

Constructed wetlands (CWs) are engineered wetland systems designed to stimulate the natural processes based on interactions among substrate media, microorganisms, and plants for the treatment of wastewaters. CWs have the advantages of low energy consumption and low costs, reduced and easy maintenance, are environmentally friendly, and have a high potential for application in developing countries and small rural communities [10-12]. Originally, CWs were designed and operated for the removal of organic matter, suspended solids, nitrogen, and phosphorus from wastewater [13-15]. CWs have also been applied for remediation of contaminated groundwater with nitrate-nitrogen $\left(\mathrm{NO}_{3}{ }^{-}-\mathrm{N}\right)[16]$, chlorinated solvents [17,18], benzene, and methyl-tert-butyl-ester (MTBE) $[19,20]$. However, there are very few studies investigating $\mathrm{NH}_{4}{ }^{+}-\mathrm{N}$ removal from contaminated groundwater by CWs. Seeger et al. [21] reported the performance of a CW for treating a groundwater multiple-contaminated with $20 \mathrm{mg} \mathrm{L}^{-1}$ benzene (99\% removal), $3.7 \mathrm{mg} \mathrm{L}^{-1} \mathrm{MTBE}$ ( $82 \%$ removal), and $45 \mathrm{mg} \mathrm{L}^{-1} \mathrm{NH}_{4}{ }^{+}-\mathrm{N}$ (54\% removal). The potential of $\mathrm{CWs}$ to remove $\mathrm{NH}_{4}{ }^{+}-\mathrm{N}$ from contaminated groundwater, and the process for highly efficient and sustainable $\mathrm{NH}_{4}{ }^{+}-\mathrm{N}$ removal, are still unclear.

In natural freshwater sediments and CWs, microorganism-mediated nitrification and denitrification are the major pathways for $\mathrm{NH}_{4}{ }^{+}-\mathrm{N}$ removal [22-24]. Nitrification and denitrification require aerobic and anaerobic conditions, respectively, which makes it difficult to promote both nitrification and denitrification in a single CW [25]. To address this issue, tidal flow CWs operated with a repeated cycle consisting of fill, contact (flooded), drain, and rest period have recently attracted attention [26]. During the drain and rest period, air can be drawn into substrate media from the atmosphere, following which substrate media can have aerobic conditions. During the flooded period, air can be released from the media and consumed by microbial reactions, resulting in anaerobic conditions in the media and water phase. Tidal flow CWs thus can provide appropriate aerobic/anaerobic conditions for both nitrification and denitrification processes $[27,28]$. In addition to the flow type, substrate media can also affect $\mathrm{NH}_{4}{ }^{+}-\mathrm{N}$ removal in CWs. Zeolite, with high porosity and high cation exchange capacity (especially for $\mathrm{NH}_{4}{ }^{+}-\mathrm{N}$ ), has been recognized as an ideal substrate material in CWs [29-31]. For sustainable and effective use, regeneration of zeolite adsorbed with $\mathrm{NH}_{4}{ }^{+}-\mathrm{N}$ is necessary. Tidal flow CWs enable the in-situ biological regeneration of zeolites due to the $\mathrm{NH}_{4}{ }^{+}-\mathrm{N}$ removal via stimulated nitrification/denitrification. If this hypothesis is verified, the tidal flow and zeolite-based CWs will offer a highly efficient and sustainable way to remove $\mathrm{NH}_{4}{ }^{+}-\mathrm{N}$ from the contaminated groundwater. However, to the best of our knowledge, there are no studies clearly showing the potential to remove $\mathrm{NH}_{4}{ }^{+}-\mathrm{N}$ from contaminated groundwater by tidal flow CWs.

This study investigates the removal efficiency of $\mathrm{NH}_{4}{ }^{+}-\mathrm{N}$ from contaminated groundwater by a tidal flow, zeolite-based CW. Laboratory-scale tidal flow zeolite-based CWs were set up and used to treat synthetic groundwater contaminated with $30 \mathrm{mg} \mathrm{L}^{-1}$ of NH$_{4}{ }^{+}-\mathrm{N}$. The advantages of nitrogen $(\mathrm{N})$ removal, including $\mathrm{NH}_{4}{ }^{+}-\mathrm{N}$ adsorption on zeolite, nitrification and denitrification by the tidal flow $\mathrm{CW}$ over continuous flow $\mathrm{CW}$, and the effect of vegetation on these $\mathrm{N}$ removal functions in CWs, are discussed below.

\section{Materials and Methods}

\subsection{Synthetic $\mathrm{NH}_{4}{ }^{+}-\mathrm{N}$ Contaminated Groundwater}

A synthetic groundwater containing $30 \mathrm{mg} \mathrm{L}^{-1}$ of $\mathrm{NH}_{4}{ }^{+}-\mathrm{N}$ was prepared and used in this study. The composition of synthetic groundwater included: $\mathrm{Na}_{2} \mathrm{HPO}_{4} \cdot 12 \mathrm{H}_{2} \mathrm{O}\left(104.5 \mathrm{mg} \mathrm{L}{ }^{-1}\right)$, $\mathrm{KH}_{2} \mathrm{PO}_{4}\left(17 \mathrm{mg} \mathrm{L}^{-1}\right), \mathrm{NaCl}\left(37.5 \mathrm{mg} \mathrm{L}^{-1}\right), \mathrm{KCl}\left(17.5 \mathrm{mg} \mathrm{L}^{-1}\right), \mathrm{CaCl}_{2} \cdot 2 \mathrm{H}_{2} \mathrm{O}\left(23 \mathrm{mg} \mathrm{L}^{-1}\right), \mathrm{MgSO}_{4} \cdot 7 \mathrm{H}_{2} \mathrm{O}$ $\left(25.6 \mathrm{mg} \mathrm{L}^{-1}\right), \mathrm{NaHCO}_{3}\left(353 \mathrm{mg} \mathrm{L}^{-1}\right)$, and $\left(\mathrm{NH}_{4}\right)_{2} \mathrm{SO}_{4}\left(141.6 \mathrm{mg} \mathrm{L}^{-1}\right)$. The constituents and their concentrations in the synthetic groundwater were determined on the basis of the chemical composition of $\mathrm{NH}_{4}{ }^{+}-\mathrm{N}$-contaminated groundwater sampled from the Kathmandu Valley, Nepal [32]. In addition, the $\mathrm{NO}_{3}{ }^{-}-\mathrm{N}$ contaminated groundwater with $30 \mathrm{mg} \mathrm{L}^{-1}$ of $\mathrm{NO}_{3}{ }^{-}-\mathrm{N}\left(182.12 \mathrm{mg}\right.$ of $\mathrm{NaNO}_{3}$ per $\mathrm{L}$, 
instead of $\left(\mathrm{NH}_{4}\right)_{2} \mathrm{SO}_{4}$ in the above $\mathrm{NH}_{4}{ }^{+}-\mathrm{N}$ contaminated groundwater) was prepared and used in the denitrification experiment.

\subsection{Experimental Setup and Conditions}

2.2.1. $\mathrm{N}$ Removal from $\mathrm{NH}_{4}{ }^{+}-\mathrm{N}$ Contaminated Groundwater by Tidal Flow CWs and Continuous Flow CWs

Here, we investigated the effect of the flow type, i.e., tidal and continuous flows, on the $\mathrm{N}$ removal abilities of CWs. Two types of laboratory-scale CWs: (i) tidal flow, and (ii) continuous flow, were set up in duplicate inside a greenhouse without artificial lights and temperature controllers at the University of Yamanashi, Kofu, Yamanashi, Japan. For each CW, a plastic column (150 mm diameter $\times$ $650 \mathrm{~mm}$ height) with an outflow port at the bottom was used. The columns were filled with pumice rock (grain size of about $10 \mathrm{~mm}$ ) from bottom to $20 \mathrm{~mm}$ height, and zeolite (grain size of 3-5 $\mathrm{mm}$ ), from 20 to $600 \mathrm{~mm}$ height. Common reed seedlings (Phragmites australis; 20 numbers; 700-900 mm tall) were planted in each CW. The side surface parts of the CWs were wrapped with silver color plastic sheets to block sunlight. The configurations of the two types of CW are shown in Figure 1. The CWs were set up at the end of July, and subjected to a 2-week start-up period for the inoculation and colonization of microorganisms into CW. During the start-up period, each $\mathrm{CW}$ was operated in a tidal flow (21-h flooded and 3-h rest) for 2 weeks. In the first week, each CW was filled with $4 \mathrm{~L}$ of synthetic groundwater mixed with activated sludge (100:1, v/v). In the following week, each CW was filled with $4 \mathrm{~L}$ of synthetic groundwater. The activated sludge was collected from the activated sludge settling tank at a conventional municipal wastewater treatment plant in Kofu, Yamanashi, Japan. Following the start-up period, two CWs were operated as tidal flow CWs (21-h flooded with $4 \mathrm{~L}$ of synthetic groundwater, and 3-h rest). Tidal flow (inflow and outflow) was controlled by a pump (Masterflex L/S; Cole-Parmer, IL, US) with a timer. The other two CWs were operated as continuous flow CWs $\left(4 \mathrm{~L} \mathrm{~d}^{-1}\right)$ with a pump, as a control experiment. The $\mathrm{N}$ removal experiments using the tidal flow and continuous flow CWs continued for 105 days from mid-August to late November. Influent and effluent samples were collected from all CWs, and their $\mathrm{NH}_{4}{ }^{+}-\mathrm{N}, \mathrm{NO}_{2}{ }^{-}-\mathrm{N}$, and $\mathrm{NO}_{3}{ }^{-}-\mathrm{N}$ concentrations were determined.

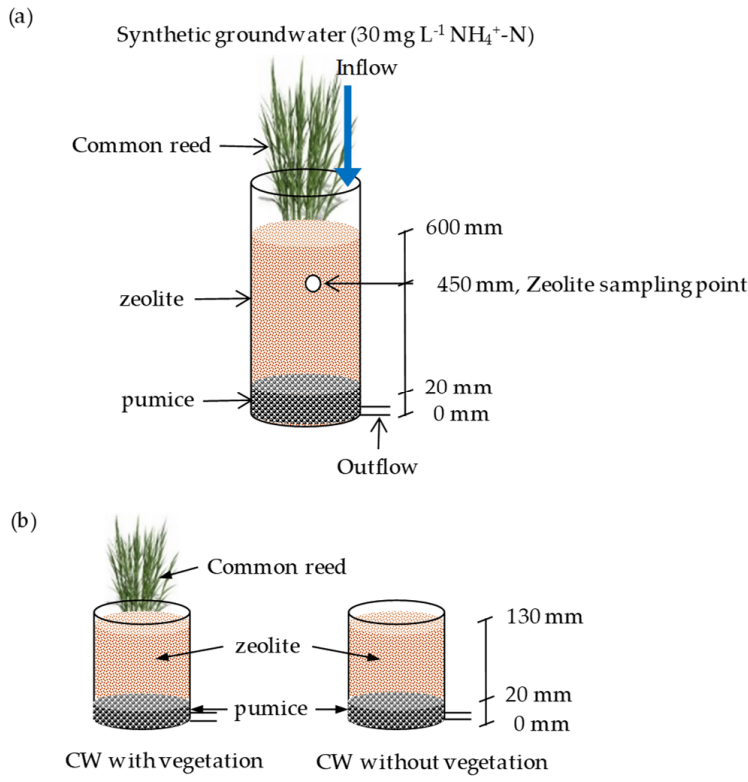

Figure 1. (a) Laboratory-scale zeolite-based tidal flow and continuous flow constructed wetlands (CWs) with vegetation (common reed plants), to study the effect of flow type in $\mathrm{N}$ removal and (b) smaller-scale tidal flow CWs, with and without vegetation, to study the effect of vegetation. 
A flowchart of this experiment is shown in Figure S1. During the experimental period, N removal potential of zeolite materials in both CWs was monitored every two weeks, as follows. Zeolite materials (100 g) were collected from each CW at $150 \mathrm{~mm}$ depth sampling point (Figure 1) and transferred into a $200 \mathrm{~mL}$ flask. The flasks were filled with $100 \mathrm{~mL}$ of synthetic $\mathrm{NH}_{4}{ }^{+}-\mathrm{N}$ contaminated groundwater $\left(30 \mathrm{mg} \mathrm{L}^{-1}\right.$ ) and incubated at $120 \mathrm{rpm}$ and $25^{\circ} \mathrm{C}$ for $24 \mathrm{~h}$. The groundwater samples were collected every few hours from flasks; and their $\mathrm{NH}_{4}{ }^{+}-\mathrm{N}, \mathrm{NO}_{2}{ }^{-} \mathrm{N}$, and $\mathrm{NO}_{3}{ }^{-}-\mathrm{N}$ concentrations were determined. The results were used for the calculation of the kinetic constant of $\mathrm{NH}_{4}{ }^{+}-\mathrm{N}$ adsorption.

\subsubsection{Evaluation of Vegetation Effects on N Removal Ability in the Tidal Flow CW}

We examined the effects of vegetation on $\mathrm{N}$ removal ability and characteristics in the tidal flow CW. A flowchart of this experiment is shown in Figure S1. The smaller-scale tidal flow CWs with and without vegetation were prepared with four $1 \mathrm{~L}$-capacity plastic beakers $(100 \mathrm{~mm}$ diameter, $140 \mathrm{~mm}$ height; Figure 1) with a drain port at the bottom. The beakers were filled with pumice rock (grain size of about $10 \mathrm{~mm}$ ) from bottom to $20 \mathrm{~mm}$ height, and zeolite (grain size of 3-5 mm), from 20 to $130 \mathrm{~mm}$ height. Common reed seedlings (10 numbers; $500-600 \mathrm{~mm}$ tall) were planted in each of the two CWs (CWs with vegetation). The other two CWs were not vegetated with common reed seedlings (CWs without vegetation). To collect water samples, a 10-mm diameter sampling port was made at $100 \mathrm{~mm}$ depth from the surface level. The side surface parts of the CWs were wrapped with silver color plastic sheets to block sunlight. At first, a 2-week start-up period was set to inoculate and colonize microorganisms into substrate media in CWs. During the start-up period, each CW was operated in the tidal flow (21-h flooded and 3-h rest). In the first week, each CW was filled with $0.5 \mathrm{~L}$ of synthetic groundwater mixed with activated sludge (100:1, v/v). In the following week, each CW was filled with $0.5 \mathrm{~L}$ of synthetic groundwater. Following the start-up period, four CWs were operated in a tidal flow (21-h flooded with $0.5 \mathrm{~L}$ of synthetic groundwater, and 3-h rest) for 60 days, from the first of September to the end of October. The tidal flow (inflow and outflow) was controlled by a pump (Masterflex) with a timer. On the 60th day, water samples were collected every few hours after filling from the sampling port of all CWs, and their $\mathrm{NH}_{4}{ }^{+}-\mathrm{N}, \mathrm{NO}_{2}{ }^{-}-\mathrm{N}$, and $\mathrm{NO}_{3}{ }^{-}-\mathrm{N}$ concentrations were determined. Furthermore, zeolite materials were collected from the CWs, both with and without vegetation, in order to analyze bacterial community.

\subsubsection{Denitrification Experiments Using Common Reed Roots from Tidal Flow CWs}

The effect of common reed roots on denitrification in CWs was examined. A flowchart of this experiment is shown in Figure S1. Zeolite (100 g) was collected from the tidal flow CWs with and without vegetation on the 60th day (Section 2.2.2) and transferred into a $100 \mathrm{~mL}$ vial, and $5 \mathrm{~g}$ (wet) of common reed roots was collected from the CWs with vegetation and added to the vial. Synthetic $\mathrm{NO}_{3}{ }^{-}-\mathrm{N}$ contaminated groundwater $(50 \mathrm{~mL})$, containing $30 \mathrm{mg}$ of $\mathrm{NO}_{3}{ }^{-}-\mathrm{N} \mathrm{L}^{-1}$, was added to each vial. The vials with and without common reed roots were prepared in triplicate. All vials were purged with nitrogen $\left(\mathrm{N}_{2}\right)$ gas for $2 \mathrm{~min}$ to create anaerobic conditions, and the vials were closed with a butyl-rubber and aluminum cap. All vials were incubated at $120 \mathrm{rpm}$ and $25^{\circ} \mathrm{C}$ for $24 \mathrm{~h}$. Water samples were collected from the vials every few hours, and their $\mathrm{NH}_{4}{ }^{+}-\mathrm{N}, \mathrm{NO}_{2}{ }^{-}-\mathrm{N}$, and $\mathrm{NO}_{3}{ }^{-}-\mathrm{N}$ concentrations were determined.

\subsection{Analysis of Samples}

Water samples were filtered through a membrane filter (polypropylene, pore size $=0.45 \mu \mathrm{m}$; Membrane Solutions Co. Ltd., Minato-ku, Japan). N concentrations in the water samples were measured in accordance with the Standard Methods for the Examination of Water and Wastewater [33]. Concentrations of $\mathrm{NH}_{4}{ }^{+}-\mathrm{N}, \mathrm{NO}_{2}{ }^{-}-\mathrm{N}$, and $\mathrm{NO}_{3}{ }^{-}-\mathrm{N}$ were determined by indophenol method, $\mathrm{N}$-(1-naphthyl) ethylenediamine method, and ultraviolet spectrophotometric screening method, respectively, with a spectrophotometer (UVmini-1280; Shimadzu Co. Ltd., Japan). 
$\mathrm{N}$ removal efficiency in the tidal flow and continuous flow zeolite-based CWs (Section 2.2.1) was calculated using Equation (1).

$$
N \text { removal efficiency }=\left(1-\frac{\text { Effluent }-N}{\text { Influent }-N}\right) \times 100 \%
$$

where Influent- $\mathrm{N}$ and Effluent- $\mathrm{N}$ represent the sum of $\mathrm{NH}_{4}{ }^{+}-\mathrm{N}, \mathrm{NO}_{2}{ }^{-}-\mathrm{N}$, and $\mathrm{NO}_{3}{ }^{-}-\mathrm{N}$ in influent and effluent, respectively.

First-order $\mathrm{NH}_{4}{ }^{+}-\mathrm{N}$ removal rate in $\mathrm{N}$ removal potential experiment (Section 2.2.1) was calculated as Equation (2).

$$
\text { First }- \text { order removal rate }=\left(\frac{\operatorname{Ln} C_{1}-\operatorname{Ln} C_{2}}{t_{1}-t_{2}}\right)
$$

where $C_{1}$ and $C_{2}$ are the concentrations of $\mathrm{NH}_{4}{ }^{+}-\mathrm{N}$ at time $t_{1}$ and $t_{2}$, respectively.

\subsection{Microbial Community Analyses}

A flowchart of microbial community analyses is shown in Figure S1. To detach the microorganisms from the zeolite substrates, zeolite $(2 \mathrm{~g})$ was weighed and placed in a $15 \mathrm{~mL}$ tube. Following this, each sample was vortexed for $1 \mathrm{~min}$ with $4 \mathrm{~mL}$ of phosphate buffer saline $\left(1.44 \mathrm{~g} \mathrm{~L}^{-1} \mathrm{NaH}_{2} \mathrm{PO}_{4}, 0.24 \mathrm{~g} \mathrm{~L}^{-1}\right.$ $\mathrm{K}_{2} \mathrm{HPO}_{4}, 8 \mathrm{~g} \mathrm{~L}^{-1} \mathrm{NaCl}, 0.2 \mathrm{~g} \mathrm{~L}^{-1} \mathrm{KCl} ; \mathrm{pH}$ 7.4), and shaken for $1 \mathrm{~min}$. The suspension was passed through a membrane filter (pore size $0.2 \mu \mathrm{m}$; mixed cellulose esters membrane; Merck Millipore). The total DNA of the microorganisms on the membrane filter was extracted by using the Nucleo-spin soil kit (MACHEREY-NAGEL GmbH, Duren, Germany), according to the manufacturer's protocol. Bacterial 16S rRNA and the ammonia monooxygenase ( $a m o A)$ of ammonia-oxidizing bacteria (AOB), nitrite oxidoreductase ( $n \times r A$ ), nitrate reductase (narG), nitrite reductase (nirK and nirS), and nitrous oxide reductase (nosZ) genes were quantified by real-time quantitative polymerase chain reaction (RT-qPCR) in a Thermal Cycler Dice RealTime System II (Takara Bio Inc., Shiga, Japan). Each $25 \mu \mathrm{L}$ reaction mixture contained $12.5 \mu \mathrm{L}$ of SYBR Premix Ex Taq (TaKaRa Bio), $0.5 \mu \mathrm{M}$ of each forward and reverse primer (Table S1), $2 \mu \mathrm{L}$ of template DNA, and $9.5 \mu \mathrm{L}$ of deionized $\mathrm{H}_{2} \mathrm{O}$. The qPCR reaction conditions were as follows: initial denaturation by pre-heating at $95^{\circ} \mathrm{C}$ for $30 \mathrm{~s}, 40$ cycles at $98{ }^{\circ} \mathrm{C}$ for $5 \mathrm{~s}$, annealing at the specified temperatures (which varied with primer type [34-40]; Table S1) for $50 \mathrm{~s}$, and an extension at $72{ }^{\circ} \mathrm{C}$ for $1 \mathrm{~min}$, followed by a dissociation stage $\left(95^{\circ} \mathrm{C}\right.$ for $15 \mathrm{~s}, 60^{\circ} \mathrm{C}$ for $30 \mathrm{~s}$, and $95^{\circ} \mathrm{C}$ for $15 \mathrm{~s}$ ). A standard curve was plotted for each gene using a synthetic plasmid carrying the target sequence. All qPCRs were conducted in triplicate, and the average gene abundances in the substrates (copies $\mathrm{g}^{-1}$ of the zeolite substrate) were calculated for each CW.

The extracted bacterial DNA samples were also subjected to Illumina MiSeq $16 \mathrm{~S}$ rRNA gene sequencing (Illumina, San Diego, CA, USA). The V4 region of the 16S rRNA gene was amplified by PCR with the universal primers 515F (5'-Seq A-TGT-GCC-AGC-MGC-CGC-GGT-AA-3') and 806R (5'-Seq B-GGA-CTA-CHV-GGG-TWT-CTA-AT-3'). PCR amplicons were sequenced in an Illumina MiSeq Sequencer (Illumina, San Diego, CA, USA). Sequence reads were analyzed with Sickle v. 1.33 [41], Fastx Toolkit v. 0.0.13.2 [42], FLASH v. 1.2.10 [43], and USEARCH v. 8.0.1623_i86linux64 [44]. In these analyses, contigs were formed, and error sequences and chimeras were removed. All operational taxonomic units (OTUs) were clustered at a cutoff of 0.03 (97\% similarity). Only phylogenetic groups accounting for more than $1 \%$ relative abundance in at least one of the datasets were listed $(\leq 1 \%$ were summed as "others"). Sequencing and sequence-read analyses were conducted at FASMAC (Kanagawa, Japan).

\subsection{Statistical Analysis}

The mean and standard deviation (SD) of the physicochemical parameters and nitrogen concentrations were calculated. Gene abundances $( \pm \mathrm{SD})$ in the zeolite substrate of each $\mathrm{CW}$ were 
also calculated. A $t$-test was used to compare the pairs of groups for significant differences $(p<0.05)$. The data were processed in SPSS v. 20 (IBM Corp., Armonk, NY, USA).

\section{Results}

\section{1. $\mathrm{N}$ Removal from $\mathrm{NH}_{4}{ }^{+}-\mathrm{N}$ Contaminated Groundwater by Tidal Flow and Continuous Flow $\mathrm{CWs}$}

The changes in $\mathrm{N}$ concentrations in influent and effluent, and the $\mathrm{N}$ removal efficiency of the tidal flow and continuous flow CWs over 105 days are shown in Figure 2. In the tidal flow CWs, $\mathrm{NH}_{4}{ }^{+}-\mathrm{N}$ and $\mathrm{NO}_{2}{ }^{-}-\mathrm{N}$ were not detected in the effluent throughout the experiment period. The $\mathrm{NO}_{3}{ }^{-}-\mathrm{N}$ concentration in the effluent ranged between 0.6 to $4.8 \mathrm{mg} \mathrm{L}^{-1}$. The $\mathrm{N}$ removal efficiency of the tidal flow $\mathrm{CW}$ was $83.9 \%-98.2 \%$. In the continuous flow $\mathrm{CW}, \mathrm{NH}_{4}{ }^{+}-\mathrm{N}$ was not detected in the effluent for the first 21 days, and its concentration increased during the 21-63-day period, ranging between 6.4 to $7.9 \mathrm{mg} \mathrm{L}^{-1}$. The $\mathrm{NO}_{2}{ }^{-}-\mathrm{N}$ was not detected in the effluent throughout the experiment period. The $\mathrm{NO}_{3}{ }^{-}-\mathrm{N}$ concentration in the effluent was between 0.4 to $3.5 \mathrm{mg} \mathrm{L}^{-1}$ over 105 days. The $\mathrm{N}$ removal efficiency of the continuous flow $\mathrm{CW}$ was $67.6 \%-97.2 \%$. After the 21 st day, $\mathrm{NH}_{4}{ }^{+}-\mathrm{N}$ concentration in the effluent was significantly lower $(p<0.05)$ in the tidal flow $\mathrm{CW}$, compared to the continuous flow $\mathrm{CW}$, and the $\mathrm{N}$ removal by the tidal flow $\mathrm{CW}$ was significantly higher $(p<0.05)$ than that by the continuous flow $\mathrm{CW}$.

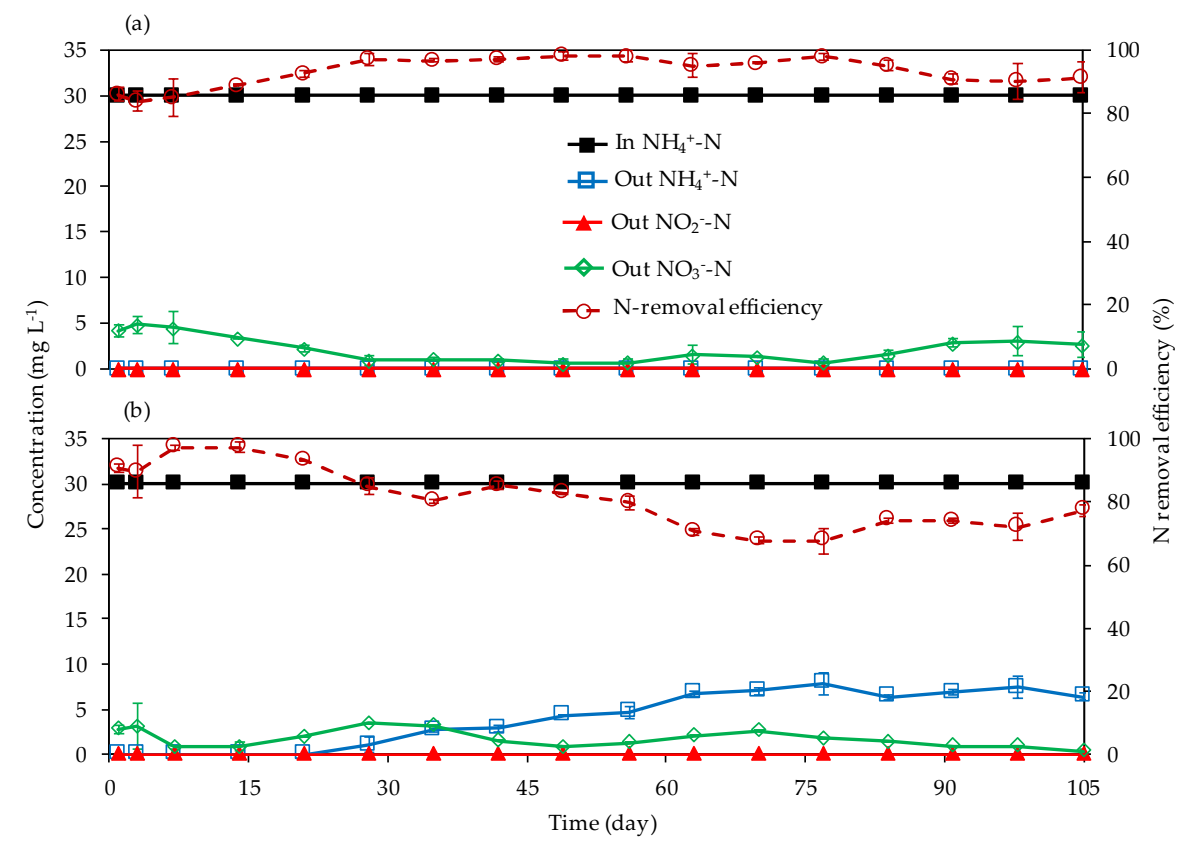

Figure 2. Changes in $\mathrm{NH}_{4}{ }^{+}-\mathrm{N}, \mathrm{NO}_{2}{ }^{-}-\mathrm{N}$, and $\mathrm{NO}_{3}{ }^{-}-\mathrm{N}$ concentration and $\mathrm{N}$ removal efficiency over 105 days of CW operation in (a) tidal flow, and (b) continuous flow. Values are means \pm SD $(n=2)$.

The results of the $\mathrm{N}$ removal potential of zeolite-microbe association of both CWs are shown in Figure 3. The $\mathrm{NH}_{4}{ }^{+}-\mathrm{N}$ removal was due to adsorption on zeolite and nitrification by microorganisms. The results clearly show a higher $\mathrm{N}$ removal by zeolite-microbe association in the tidal flow $\mathrm{CW}$, compared to that in the continuous flow $\mathrm{CW}$. The changes in $\mathrm{NH}_{4}{ }^{+}-\mathrm{N}$ concentration during the first 2-3 h (Figure 3) were fitted to the first-order kinetic model (Figure S2). Because $\mathrm{NO}_{2}{ }^{-} \mathrm{N}$ and $\mathrm{NO}_{3}{ }^{-}-\mathrm{N}$ were not generated during the first $2-3 \mathrm{~h}, \mathrm{NH}_{4}{ }^{+}-\mathrm{N}$ must have been removed by adsorption on zeolite rather than nitrification $\left(\mathrm{NH}_{4}{ }^{+}-\mathrm{N}\right.$ oxidation to $\mathrm{NO}_{2}{ }^{-}-\mathrm{N}$ and $\left.\mathrm{NO}_{3}{ }^{-}-\mathrm{N}\right)$. Thus, the first-order $\mathrm{NH}_{4}{ }^{+}-\mathrm{N}$ removal rate can be considered as the $\mathrm{NH}_{4}{ }^{+}-\mathrm{N}$ adsorption rate on zeolite. The first-order $\mathrm{NH}_{4}{ }^{+}-\mathrm{N}$ adsorption rates are summarized in Figure 4. The $\mathrm{NH}_{4}{ }^{+}-\mathrm{N}$ adsorption kinetic constants of zeolite-microbe in both the tidal flow and continuous flow CWs decreased gradually. However, the $\mathrm{NH}_{4}{ }^{+}-\mathrm{N}$ adsorption rates of the tidal flow CWs were higher than those of the continuous flow CWs. 
(a)
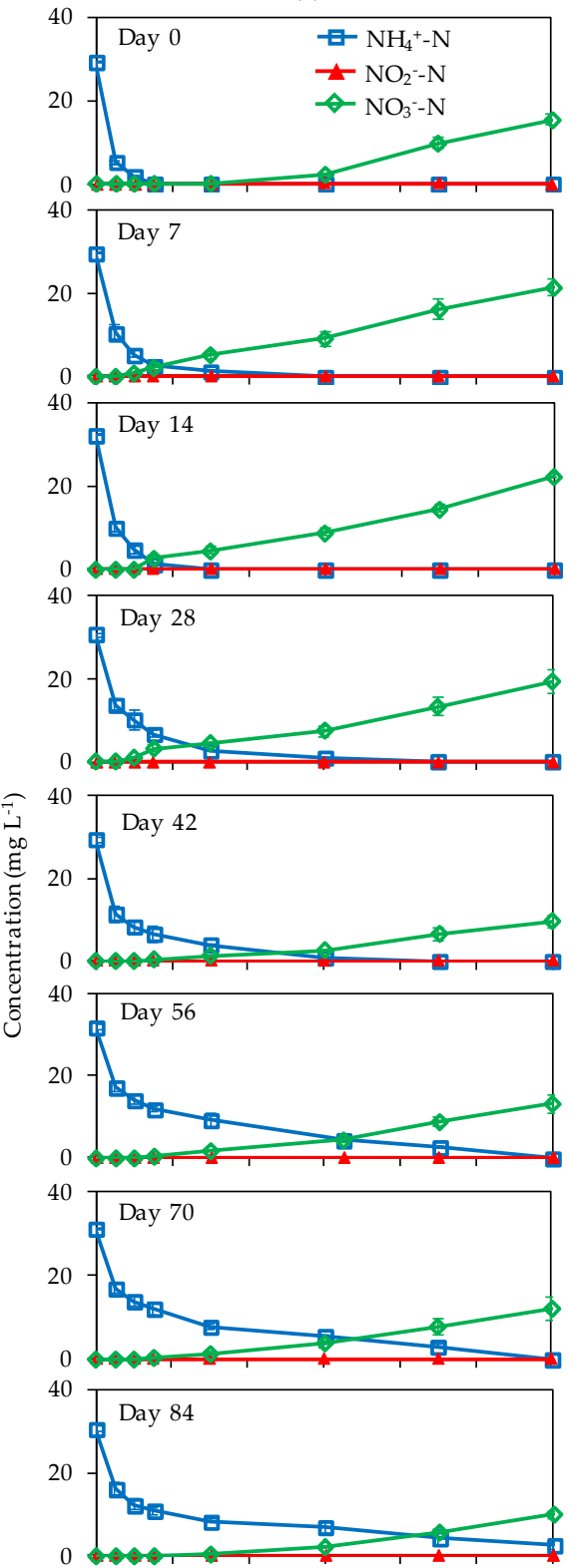

40 Day 98
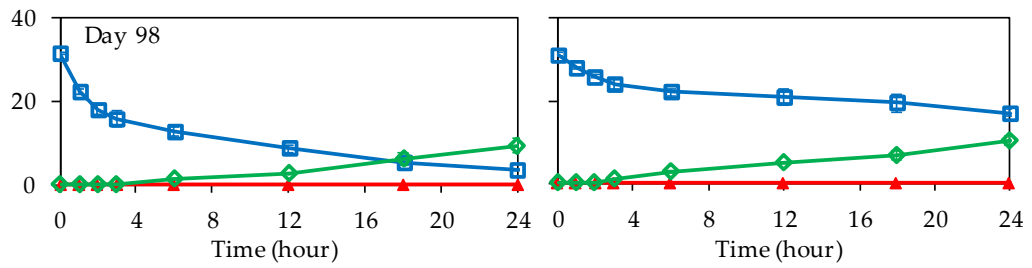

Figure 3. N removal potential of zeolite-microbe association in (a) tidal flow CWs, and (b) continuous flow CWs. Values are means $\pm \operatorname{SD}(n=3)$. (b)
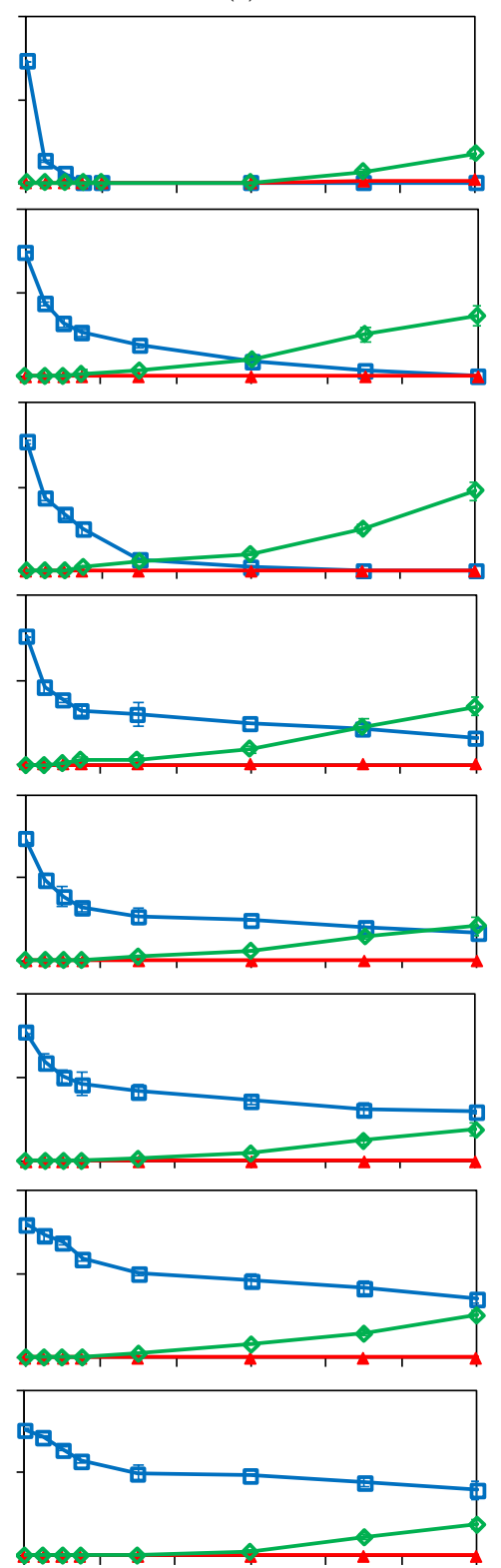


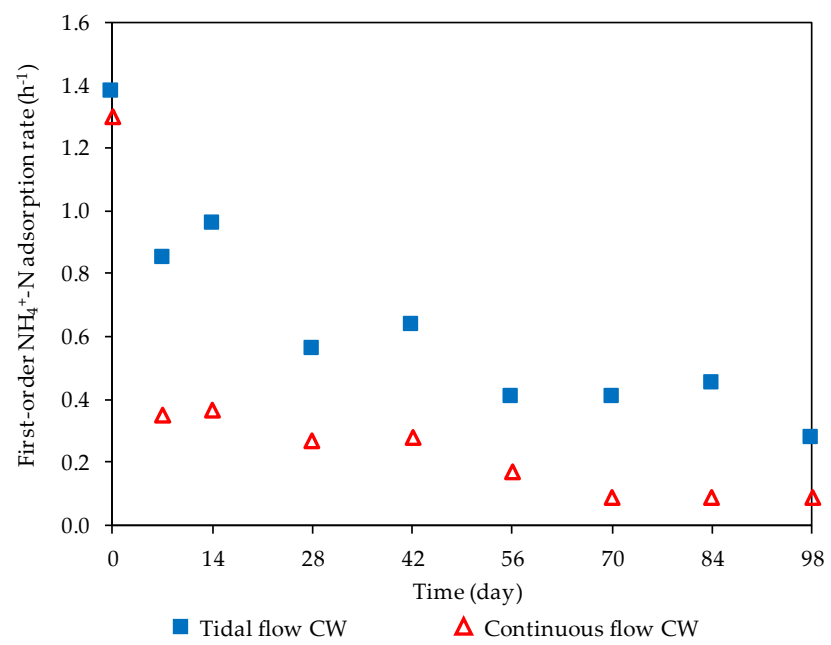

Figure 4. First-order $\mathrm{NH}_{4}{ }^{+}-\mathrm{N}$ adsorption rate on zeolites in tidal flow $\mathrm{CWs}$ and continuous flow CWs.

\subsection{Evaluation of Vegetation Effects on N Removal Ability in the Tidal Flow CWs}

The change of $\mathrm{N}$ concentrations over time in the tidal flow CWs with and without vegetation after 60 days of operation are shown in Figure 5. In the tidal flow $\mathrm{CW}$ with vegetation, $\mathrm{NH}_{4}{ }^{+}-\mathrm{N}$ concentration rapidly and completely decreased within $3 \mathrm{~h}$. The $\mathrm{NO}_{3}{ }^{-}-\mathrm{N}$ concentration rapidly increased for $2 \mathrm{~h}$, and then gradually and completely decreased within $18 \mathrm{~h}$. The $\mathrm{NO}_{2}{ }^{-}-\mathrm{N}$ concentration was not detected for $24 \mathrm{~h}$. In the tidal flow $\mathrm{CW}$ without vegetation, $\mathrm{NH}_{4}{ }^{+}-\mathrm{N}$ concentration decreased rapidly and completely within $9 \mathrm{~h}$. The $\mathrm{NO}_{2}{ }^{-}-\mathrm{N}$ and $\mathrm{NO}_{3}{ }^{-}-\mathrm{N}$ concentrations increased for $3 \mathrm{~h}$, following which $\mathrm{NO}_{2}{ }^{-}-\mathrm{N}$ concentration decreased; however, the $\mathrm{NO}_{3}{ }^{-}-\mathrm{N}$ concentration increased gradually for $24 \mathrm{~h}$. The difference in the dynamics of $\mathrm{NO}_{3}{ }^{-}-\mathrm{N}$ concentration between $\mathrm{CWs}$ with and without vegetation might be due to the occurrence of denitrification in CWs. Previous studies have shown that the contribution of plant uptake to $\mathrm{N}$ removal in CWs is lesser than biological nitrification/denitrification [23,45].

(a)

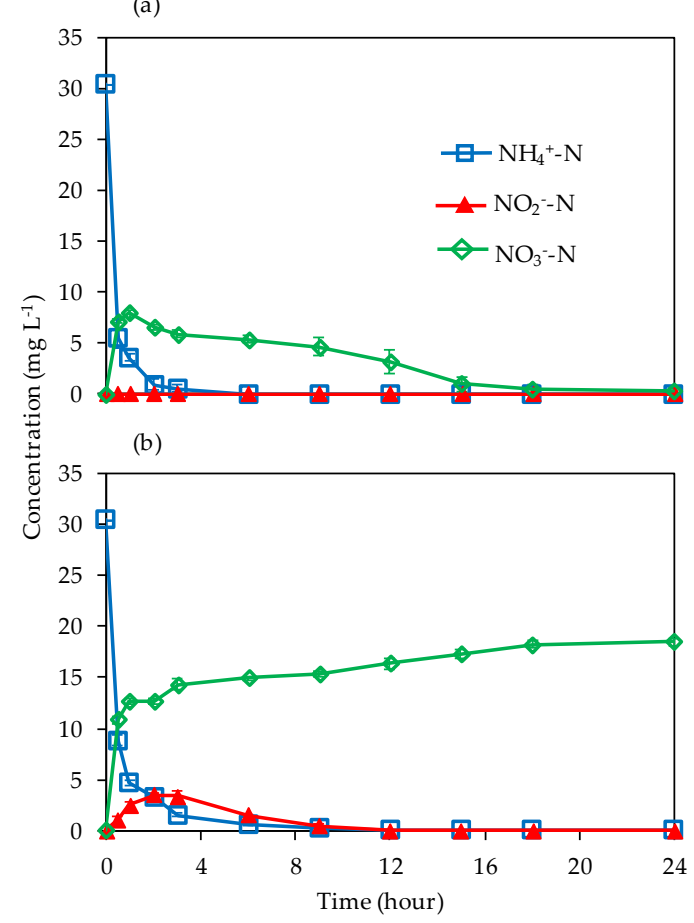

Figure 5. Changes in $\mathrm{N}$ concentrations in groundwater inside tidal flow CWs: (a) with vegetation (common reed plants), and (b) without vegetation. Values are means $\pm \operatorname{SD}(n=3)$. 


\subsection{Denitrification Experiments Using Common Reed Roots from Tidal Flow CWs}

The changes in $\mathrm{N}$ concentrations in the effluent of denitrification experiments in zeolite-microbe with common reed roots and zeolite-microbe without roots are shown in Figure 6. In zeolite-microbe with roots, $\mathrm{NO}_{3}{ }^{-}-\mathrm{N}$ concentration decreased completely within $24 \mathrm{~h}$, whereas it decreased slightly, from 30 to $24 \mathrm{mg} \mathrm{L}^{-1}$, in zeolite-microbe without roots. The results suggest that common reed roots supported denitrification.

(a)

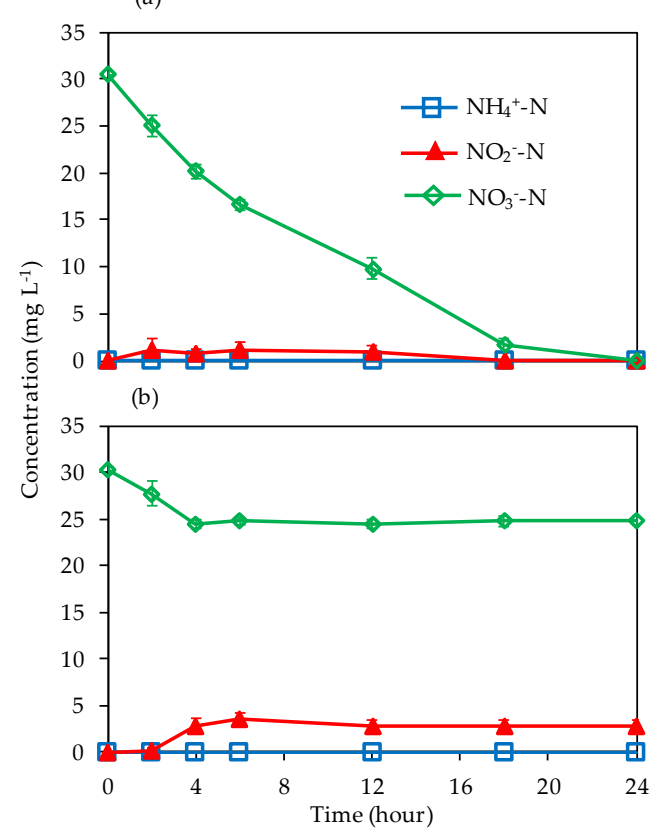

Figure 6. Changes in $\mathrm{N}$ concentrations over $24 \mathrm{~h}$ in denitrification experimental vial containing zeolite: (a) with common reed roots, and (b) without common reed roots, from the tidal flow CWs with and without vegetation, respectively, on the 60 th day of operation. Values are means $\pm \operatorname{SD}(n=3)$.

\subsection{Characterization of Microbial Communities in Tidal Flow CWs with and without Vegetation}

The abundances of bacterial 16S rRNA and AOB-amoA, nxrA, narG, nirK, nirS, and nosZ genes on the 60th day of tidal flow CWs with and without vegetation are shown in Table 1 . The abundance of $16 \mathrm{~S}$ rRNA gene, nitrifying (AOB-amoA and $n x r A$ ), and denitrifying (narG, nirK, nirS, and nosZ) functional genes were about two-three orders of magnitude higher in the tidal flow $\mathrm{CW}$ with vegetation than that without vegetation.

Table 1. Abundance of bacterial $16 \mathrm{~S}$ rRNA and ammonia oxidizing bacteria (AOB)-amoA, nxrA, narG, nirK, nirS, and nosZ genes in zeolite-based tidal flow CWs with and without vegetation (common reed plants) on the last day (i.e., 60th day) of operation. Average numbers of gene copies \pm SD are shown for triplicate experiments.

\begin{tabular}{ccc}
\hline \multirow{2}{*}{ Target Gene } & \multicolumn{2}{c}{ Abundance (copies $\mathbf{g}^{-\mathbf{1}}$ of zeolite) } \\
\cline { 2 - 3 } & with Vegetation & without Vegetation \\
\hline Bacterial 16S rRNA & $(6.6 \pm 0.8) \times 10^{10}$ & $(4.0 \pm 0.4) \times 10^{8}$ \\
AOB-amoA & $(2.6 \pm 0.9) \times 10^{8}$ & $(2.3 \pm 0.3) \times 10^{6}$ \\
nxrA & $(7.1 \pm 2.6) \times 10^{4}$ & $(7.4 \pm 1.2) \times 10^{2}$ \\
narG & $(8.6 \pm 3.6) \times 10^{8}$ & $(5.5 \pm 0.5) \times 10^{6}$ \\
nirK & $(1.4 \pm 0.6) \times 10^{8}$ & $(1.1 \pm 0.4) \times 10^{6}$ \\
nirS & $(3.1 \pm 1.1) \times 10^{8}$ & $(1.0 \pm 0.6) \times 10^{6}$ \\
nosZ & $(1.9 \pm 0.1) \times 10^{8}$ & $(5.8 \pm 0.4) \times 10^{4}$ \\
\hline
\end{tabular}


The bacterial community structures of the tidal flow CWs with and without vegetation at phylum, class, and order levels are shown in Figure 7. At phylum level, Proteobacteria (45.7\% of all phyla), Bacteroidetes (14.4\%), and Planctomycetes (6.5\%) were dominant in the tidal flow CW with vegetation; Proteobacteria (49.2\%), Bacteroidetes (25.8\%), and Verrucomicrobia (5.8\%) were dominant in the tidal flow CW without vegetation. At class level, Alphaproteobacteria (19.6\% of all classes), Betaproteobacteria (10.8\%), Gammaproteobacteria $(10.1 \%)$, and Saprospirae $(6.9 \%)$ were dominant in the tidal flow CW with vegetation; Betaproteobacteria (27.0\%), Saprospirae (21.0\%), Alphaproteobacteria (14.4\%), and Gammaproteobacteria $(5.8 \%)$ in the tidal flow $\mathrm{CW}$ without vegetation.

(a)

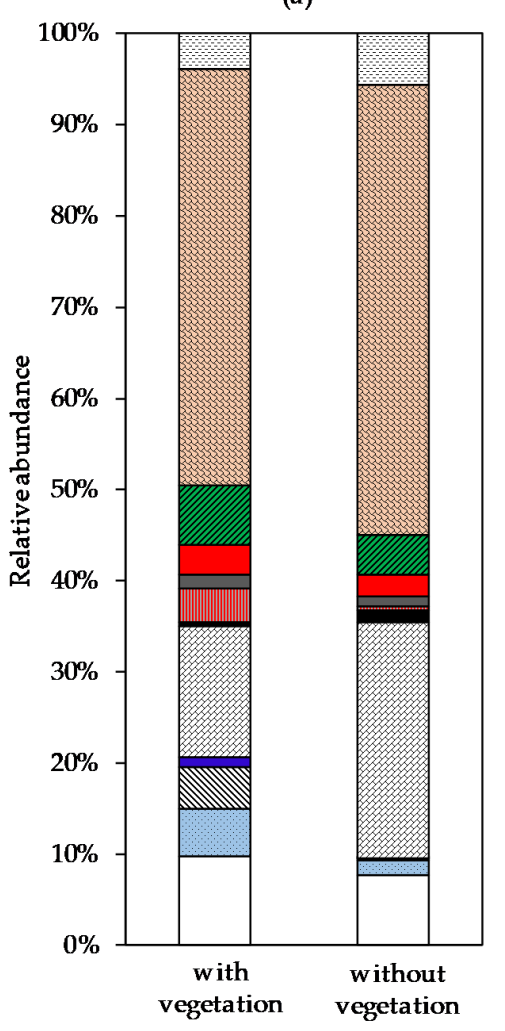

(b)

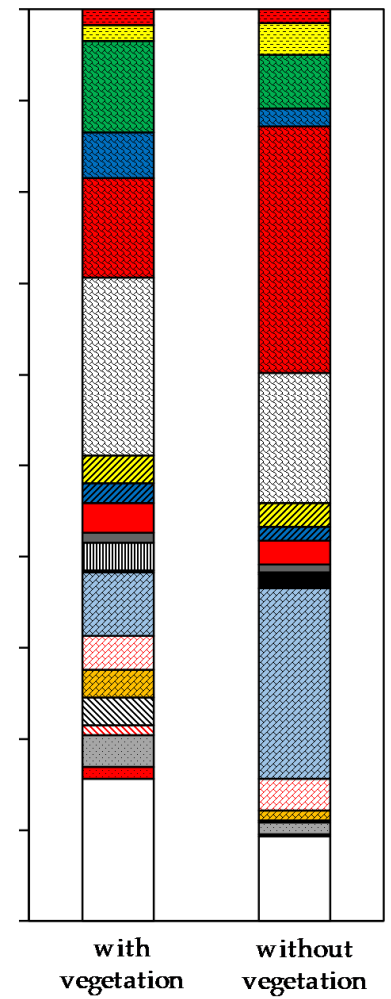

(c)

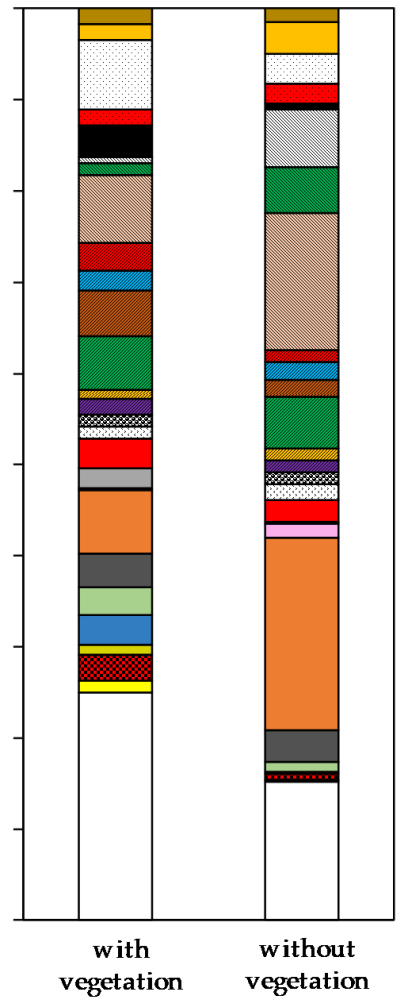

Tidal flow constructed w etlands

\begin{tabular}{|c|c|c|c|c|}
\hline Phyla & Class & & Order & \\
\hline$\square$ Others & $\square$ Others & Solibacteres & $\square$ Others & $\square$ Solibacterales \\
\hline - Acidobacteria & - [Chloracidobacteria] & \Acidimicrobüa & RBA1 & $\square$ Acidimicnobiales \\
\hline$\Delta$ Actinobacteria & $\mathbf{\otimes}$ Actinobacterüa & Q Cytophagia & Actinomycetales & $\square$ Cytophagales \\
\hline$\square$ Amatimonadetes & Sphingobacterïa & Q [Saprospime] & Sphingobacteriales & $\square$ [Saprospirales] \\
\hline Bacteridetes & Chlamydüa & III Anaenolineae & Chlamydiales & $\square$ SBR1031 \\
\hline$\square$ Chlamydiae & $\square$ Gemmatimonadetes & $\square$ Nitrospira & Nitrospirales & 5 Phycisphaerales \\
\hline & $\square$ Phycisphaerae & Planctomycetia & 8 Gemmatales & c_Alphaproteobacteria;o_ \\
\hline & Alphapnoteobacteria & Зetaproteobacteria & Caulobacterales & Rhizobiales \\
\hline Nitrospirae & Deltaproteobacteria & Gammaproteobacteria & Rhodobacterales & Rhodospinillales \\
\hline Melamalo & -7 Opitutae & Dis & Sphingomonadales & $\mathbb{N}$ Burkholderiales \\
\hline Planctomycetes & utae & Peaospraerae I & $\mathbb{N}$ Nitrosomonadales & $\mathbb{N}$ Rhodocyclales \\
\hline Q Proteobacteria & & & Myxococcales & $\square$ Legionellales \\
\hline - Vemucomicrobia & & & $\because$ Xanthomonadales & $\square$ Opitutales \\
\hline & & & $\square$ [Pedosphaerales] & \\
\hline
\end{tabular}

Figure 7. Bacterial community compositions at the (a) phylum, (b) class, and (c) order level in the tidal flow CWs with and without vegetation (common reed plants) on the last day (60th day) of operation. 
Based on the bacterial order, the dominant groups were Xanthomonadales (7.7\% of all orders), Burkholderiales (7.5\%), Saprospirales (6.9\%), and Rhizobiales $(5.9 \%)$ in the CW with vegetation, and Saprospirales (21.0\%), Burkholderiales (15.1\%), Rhodocyclales (6.3\%), and Rhizobiales (5.6\%) in the CW without vegetation. The relative abundances of Nitrosomonadales (AOB) were $1.2 \%$ and $4.9 \%$ in the CWs with and without vegetation, respectively. Further, the relative abundances of Nitrospirales (nitrite-oxidizing bacteria; NOB) were $3.3 \%$ and $2.5 \%$ in the CWs with and without vegetation, respectively. The bacterial community structure, and the relative abundances of Nitrosomonadales and Nitrospirales in the tidal flow CWs with and without vegetation were similar.

\section{Discussion}

In this study, the ability and characteristics of zeolite-based tidal flow CWs to remove $\mathrm{N}$ from $\mathrm{NH}_{4}{ }^{+}-\mathrm{N}$ contaminated groundwater were examined. The tidal flow $\mathrm{CW}$ was operated at a cycle consisting of 21-h flooded and 3-h rest, and removed $\mathrm{NH}_{4}{ }^{+}-\mathrm{N}$ completely and repeatedly from $\mathrm{NH}_{4}{ }^{+}-\mathrm{N}$ contaminated groundwater $\left(30 \mathrm{mg} \mathrm{L}{ }^{-1}\right.$ ) over 105 days (Figure 2$)$. In addition to $\mathrm{NH}_{4}{ }^{+}-\mathrm{N}_{,} \mathrm{NO}_{2}{ }^{-}-\mathrm{N}$ and $\mathrm{NO}_{3}{ }^{-}-\mathrm{N}$ were also not detected in the effluents from the tidal flow $\mathrm{CW}$ (Figure 2). The highly efficient $\mathrm{N}$ removal from $\mathrm{NH}_{4}{ }^{+}-\mathrm{N}$ contaminated groundwater and higher first-order kinetic constant for the $\mathrm{NH}_{4}{ }^{+}-\mathrm{N}$ adsorption remained high for a longer period of time, compared to the continuous flow CWs (Figures 2 and 4). Although zeolite has a high ability to remove $\mathrm{NH}_{4}{ }^{+}-\mathrm{N}$, there is a limitation to its adsorption capacity [23]. For sustainable $\mathrm{NH}_{4}{ }^{+}-\mathrm{N}$ removal by zeolite, several methods for zeolite regeneration by brine solution treatment [46], $\mathrm{NaOH}$ treatment [47], electrochemical treatment [48], and biological nitrification treatment $[49,50]$ have been reported. Tidal flow CWs have a higher atmospheric air supply and enhanced nitrification and denitrification, compared to continuous flow CWs [51,52]. Oxygen can be rapidly replenished into CW beds by the rhythmic tidal flow, and then dissolved oxygen (DO) is consumed by microbial activities for organic carbon degradation and nitrification along the depth $[53,54]$ and contacting time $[55,56]$. After that, $\mathrm{CW}$ beds can change into anaerobic conditions. Unfortunately, DO concentration and oxidation-reduction potential were not monitored in this study. Enhanced nitrification and denitrification might have resulted in the in-situ biological regeneration of zeolite in the tidal flow CWs. Therefore, the tidal flow zeolite-based CW could remove $\mathrm{N}$ sustainably from $\mathrm{NH}_{4}{ }^{+}-\mathrm{N}$ contaminated groundwater.

In the zeolite-based tidal flow CWs, vegetation with common reeds accelerated complete nitrification without accumulation of $\mathrm{NO}_{2}{ }^{-}-\mathrm{N}$ in the $\mathrm{CW}$ with vegetation, compared to the $\mathrm{CW}$ without vegetation (Figure 5). Aquatic plants can release oxygen from roots and create aerobic conditions around roots and rhizosphere, increasing the activity and population of nitrifying bacteria [57]. In this study, the abundances of nitrifying functional genes (AOB-amo $A$ and $n x r A$ genes) were also two orders of magnitude higher in the $C W$ with vegetation than those in the $C W$ without vegetation (Table 1).

In addition, vegetation with common reeds significantly stimulated denitrification in the tidal flow $\mathrm{CW}$. The decrease in $\mathrm{NO}_{3}{ }^{-}-\mathrm{N}$ concentration was significantly higher in the $\mathrm{CW}$ with vegetation and in denitrification experimental vial with roots than in the $\mathrm{CW}$ without vegetation and denitrification vial without roots, respectively (Figures 5 and 6). Aquatic plants, including common reeds, can release not only oxygen, but also organic compounds from roots into the rhizosphere [45,58]. The released organic compounds from plants can act as electron donors for heterotrophic denitrification bacteria, stimulating their activity and growth. Previous studies revealed the enhanced denitrification and higher abundance of denitrification bacteria in the CW [59] and sediment [60] with vegetation. In this study, denitrification ability and denitrifying functional genes (narG, nirK, nirS, and nosZ genes) were increased by vegetation with common reeds. The denitrification-stimulating effects of vegetation will be important and effective in $\mathrm{N}$ removal from contaminated groundwater lacking organic compounds. Although the vegetation in the CW increased the abundances of total bacteria, nitrification bacteria, and denitrification bacteria by two-three orders of magnitude compared to the CW without vegetation, the vegetation could not dramatically change the bacterial community compositions in the CWs. Proteobacteria and Bacteroidetes are generally the most dominant phyla in CWs [61-63]. In this study, the two phyla were dominant 
in both tidal flow CWs, with and without vegetation (Figure 7). Nitrosomonadales-like AOB and Nitrospirales-like NOB were also detected in both CWs, with and without vegetation, and might be one of key nitrification bacteria in the CWs.

Denitrification ability is widely spread in diverse phylogenetic groups. Various order of bacteria, like Rhizobiales (Rhizobiaceae group) and Rhodocyclales (genus; Thauera and Dechloromonas) have been found to show denitrification $[63,64]$. These were present in the CWs in this study. In addition, Planctomycetes were also present in the investigated CWs. However, their contribution to $\mathrm{N}$ removal as anaerobic ammonium oxidation (anammox) remained unclear.

CWs have been applied for wastewater treatment [13-15] and remediation of contaminated groundwater with $\mathrm{NO}_{3}{ }^{-}-\mathrm{N}$, chlorinated solvents, benzene, and MTBE $[16,17,20]$. This study is the first to demonstrate that $\mathrm{CWs}$ have potential to remove $\mathrm{N}$ from $\mathrm{NH}_{4}{ }^{+}-\mathrm{N}$ contaminated groundwater. In particular, our results found that the combination of zeolite substrate, tidal flow, and vegetation in CW is important for highly efficient and sustainable $\mathrm{N}$ removal. Pilot-scale tidal flow CWs have been operated as pump- or siphon-driven for treatment of various wastewaters $[26,62,65,66]$. Like these studies, it will be necessary to evaluate the performance of tidal flow $\mathrm{CW}$ treating $\mathrm{NH}_{4}{ }^{+}-\mathrm{N}$ contaminated groundwater in a pilot- or full-scale system.

\section{Conclusions}

This study clearly demonstrated that zeolite-based tidal flow (21-h flooded and 3-h rest) CWs are highly efficient in removing total $\mathrm{N}$ from $\mathrm{NH}_{4}{ }^{+}-\mathrm{N}\left(30 \mathrm{mg} \mathrm{L}^{-1}\right)$ contaminated groundwater in 105 days. In contrast, continuous flow CWs did not retain the higher rate of $\mathrm{N}$ removal from the $\mathrm{NH}_{4}{ }^{+}-\mathrm{N}$ contaminated groundwater. The highly efficient and sustainable $\mathrm{N}$ removal in tidal flow $\mathrm{CWs}$ might be due to the regeneration of zeolite $\mathrm{NH}_{4}{ }^{+}-\mathrm{N}$ adsorption capacity. The presence of vegetation (common reed) in the CWs enhanced nitrification and heterotrophic denitrification and increased the populations of nitrifying and denitrifying bacteria. These results strongly indicate that the major mechanism of the efficient and stable $\mathrm{N}$ removal in the zeolite-based tidal flow $\mathrm{CW}$ was a two-step process: $\mathrm{NH}_{4}{ }^{+}-\mathrm{N}$ was initially adsorbed onto zeolite and, subsequently, the adsorbed $\mathrm{NH}_{4}{ }^{+}-\mathrm{N}$ was converted to $\mathrm{NO}_{2}{ }^{-}-\mathrm{N}$ and $\mathrm{NO}_{3}{ }^{-}-\mathrm{N}$, and finally transferred to the atmosphere as $\mathrm{N}_{2}$ by enhanced nitrification and denitrification in CWs. The combination of zeolite substrate, tidal flow, and vegetation in $\mathrm{CW}$ should thus provide highly efficient and sustainable $\mathrm{N}$ removal. The knowledge obtained from this study will be helpful for the practical application of CWs to the treatment of $\mathrm{NH}_{4}{ }^{+}-\mathrm{N}$ contaminated groundwater.

Supplementary Materials: The following are available online at http://www.mdpi.com/2073-4441/12/5/1326/s1, Figure S1. The experimental flowcharts of Section 2.2.1 (a), Section 2.2.2 (b), Section 2.2.3 (c), and Section 2.4 (d); Table S1. Target genes for qPCR analysis, primers and sequences, amplification sizes, and annealing temperatures; Figure S2. First-order kinetic models for the decrease in $\mathrm{NH}_{4}{ }^{+}-\mathrm{N}$ concentrations during the first 2-3 hours of $\mathrm{N}$ removal potential experiment in zeolite-microbe association of (a) tidal flow CWs, and (b) continuous flow CWs.

Author Contributions: All authors contributed to the study design. A.K.M. and T.T. performed the experiments. A.K.M. interpreted the results and prepared a draft of the manuscript. T.T. supervised the experiments, checked and interpreted the results, and corrected the draft of the manuscript. K.M. discussed the results and critically reviewed the manuscript. All authors have read and agreed to the published version of the manuscript.

Funding: This research received no external funding.

Acknowledgments: The authors would like to thank Otsuka, Kaneko, Yamada, and Koga for their support in the experiments and lab analysis. The authors are also grateful to the editor and anonymous peer reviewers for their valuable input.

Conflicts of Interest: The authors declare no conflict of interest. 


\section{References}

1. Smith, M.; Cross, K.; Paden, M.; Laban, P. Spring: Managing Groundwater Sustainably; Smith, M., Cross, K., Paden, M., Laban, P., Eds.; IUCN: Gland, Switzerland, 2016. [CrossRef]

2. Patterson, B.M.; Grassi, M.E.; Davis, G.B.; Robertson, B.S.; McKinley, A.J. Use of polymer mats in series for sequential reactive barrier remediation of ammonium-contaminated groundwater: Laboratory column evaluation. Environ. Sci. Technol. 2002, 36, 3439-3445. [CrossRef] [PubMed]

3. Lindenbaum, J. Identification of Sources of Ammonium in Groundwater Using Stable Nitrogen and Boron Isotopes in Nam Du, Hanoi. Master's Thesis, Lund University, Lund, Sweden, 2012.

4. Huang, G.; Liu, F.; Yang, Y.; Kong, X.; Li, S.; Zhang, Y.; Cao, D. Ammonium-nitrogen-contaminated groundwater remediation by a sequential three-zone permeable reactive barrier (multibarrier) with oxygen-releasing compound (ORC)/clinoptilolite/spongy iron: Column studies. Environ. Sci. Pollut. Res. 2015, 22, 3705-3714. [CrossRef] [PubMed]

5. Choudhary, S.; Ramteke, S.; Rajhans, K.P.; Sahu, P.K.; Chakradhari, S.; Patel, K.S.; Matini, L. Assessment of Groundwater Quality in Central India. J. Water Resour. Prot. 2016, 8, 12-19. [CrossRef]

6. Shakya, B.M.; Nakamura, T.; Kamei, T.; Shrestha, S.D.; Nishida, K. Seasonal groundwater quality status and nitrogen contamination in the shallow aquifer system of the Kathmandu Valley, Nepal. Water 2019, 11, 2184. [CrossRef]

7. Huang, G.; Liu, F.; Yang, Y.; Deng, W.; Li, S.; Huang, Y.; Kong, X. Removal of ammonium-nitrogen from groundwater using a fully passive permeable reactive barrier with oxygen-releasing compound and clinoptilolite. J. Environ. Manag. 2015, 154, 1-7. [CrossRef]

8. Li, S.; Huang, G.; Kong, X.; Yang, Y.; Liu, F.; Hou, G.; Chen, H. Ammonium removal from groundwater using a zeolite permeable reactive barrier: A pilot-scale demonstration. Water Sci. Technol. 2014, 70, 1540-1547. [CrossRef]

9. Obiri-Nyarko, F.; Grajales-Mesa, S.J.; Malina, G. An overview of permeable reactive barriers for in situ sustainable groundwater remediation. Chemosphere 2014, 111, 243-259. [CrossRef]

10. Brix, H. How "green" are aquaculture, constructed wetlands and conventional wastewater treatment systems? Water Sci. Technol. 1999, 40, 45-50. [CrossRef]

11. Kadlec, R.H.; Wallace, S.D. Treatment Wetlands, 2nd ed.; CRC Press Taylor \& Francis Group: Boca Raton, FL, USA, 2009.

12. Vymazal, J.; Kropfelova, L. Wastewater Treatment in Constructed Wetlands with Horizontal Sub-Surface Flow; Springer: Berlin/Heidelberg, Germany, 2008.

13. Abdelhakeem, S.G.; Aboulroos, S.A.; Kamel, M.M. Performance of a vertical subsurface flow constructed wetland under different operational conditions. J. Adv. Res. 2016, 7, 803-814. [CrossRef]

14. Gikas, G.D.; Tsihrintzis, V.A. A small-size vertical flow constructed wetland for on-site treatment of household wastewater. Ecol. Eng. 2012, 44, 337-343. [CrossRef]

15. Yousefi, Z.; Mohseni-Bandpei, A. Nitrogen and phosphorus removal from wastewater by subsurface wetlands planted with Iris pseudacorus. Ecol. Eng. 2010, 36, 777-782. [CrossRef]

16. Lin, Y.F.; Jing, S.R.; Lee, D.Y.; Chang, Y.F.; Shih, K.C. Nitrate removal from groundwater using constructed wetlands under various hydraulic loading rates. Bioresour. Technol. 2008, 99, 7504-7513. [CrossRef] [PubMed]

17. Braeckevelt, M.; Reiche, N.; Trapp, S.; Wiessner, A.; Paschke, H.; Kuschk, P.; Kaestner, M. Chlorobenzene removal efficiencies and removal processes in a pilot-scale constructed wetland treating contaminated groundwater. Ecol. Eng. 2011, 37, 903-913. [CrossRef]

18. Amon, J.P.; Agrawal, A.; Shelley, M.L.; Opperman, B.C.; Enright, M.P.; Clemmer, N.D.; Slusser, T.; Lach, J.; Sobolewski, T.; Gruner, W.; et al. Development of a wetland constructed for the treatment of groundwater contaminated by chlorinated ethenes. Ecol. Eng. 2007, 30, 51-66. [CrossRef]

19. Bedessem, M.E.; Ferro, A.M.; Hiegel, T. Pilot-scale constructed wetlands for petroleum-contaminated groundwater. Water Environ. Res. 2007, 79, 581-586. [CrossRef]

20. Stefanakis, A.I.; Seeger, E.; Dorer, C.; Sinke, A.; Thullner, M. Performance of pilot-scale horizontal subsurface flow constructed wetlands treating groundwater contaminated with phenols and petroleum derivatives. Ecol. Eng. 2016, 95, 514-526. [CrossRef] 
21. Seeger, E.M.; Kuschk, P.; Fazekas, H.; Grathwohl, P.; Kaestner, M. Bioremediation of benzene-, MTBEand ammonia-contaminated groundwater with pilot-scale constructed wetlands. Environ. Pollut. 2011, 159, 3769-3776. [CrossRef]

22. Lee, C.; Fletcher, T.D.; Sun, G. Nitrogen removal in constructed wetland systems. Eng. Life Sci. 2009, 9, 11-22. [CrossRef]

23. Wen, Y.; Xu, C.; Liu, G.; Chen, Y.; Zhou, Q. Enhanced nitrogen removal reliability and efficiency in integrated constructed wetland microcosms using zeolite. Front. Environ. Sci. Eng. 2012, 6, 140-147. [CrossRef]

24. Reddy, K.R.; Patrick, W.H. Nitrogen transformations and loss in flooded soils and sediments. Crit. Rev. Environ. Sci. Technol. 1984, 13, 273-309. [CrossRef]

25. Vymazal, J. Horizontal sub-surface flow and hybrid constructed wetlands systems for wastewater treatment. Ecol. Eng. 2005, 25, 478-490. [CrossRef]

26. Sun, G.J.; Zhao, Y.; Allen, S.; Cooper, D. Generating "tide" in pilot-scale constructed wetlands to enhance agricultural wastewater treatment. Eng. Life Sci. 2006, 6, 560-565. [CrossRef]

27. Austin, D.; Lohan, E.; Verson, E. Nitrification and denitrification in a tidal vertical flow wetland pilot. In Water Environment Technical Conference; WEF: Los Angeles, CA, USA, 2003; pp. 333-357. [CrossRef]

28. Austin, D. Influence of cation exchange capacity (CEC) in a tidal flow, flood and drain wastewater treatment wetland. Ecol. Eng. 2006, 28, 35-43. [CrossRef]

29. Bruch, I.; Fritsche, J.; Bänninger, D.; Alewell, U.; Sendelov, M.; Hürlimann, H.; Hasselbach, R.; Alewell, C. Improving the treatment efficiency of constructed wetlands with zeolite-containing filter sands. Bioresour. Technol. 2011, 102, 937-941. [CrossRef] [PubMed]

30. Shuib, N.; Baskaran, K.; Jegatheesan, V. Evaluating the performance of horizontal subsurface flow constructed wetlands using natural zeolite (escott ). Int. J. Environ. Sci. Dev. 2011, 2, 311-315.

31. Saeed, T.; Sun, G. A review on nitrogen and organics removal mechanisms in subsurface flow constructed wetlands: Dependency on environmental parameters, operating conditions and supporting media. J. Environ. Manag. 2012, 112, 429-448. [CrossRef]

32. Khanitchaidecha, W.; Shakya, M.; Nakano, Y.; Tanaka, Y.; Kazama, F. Development of an attached growth reactor for $\mathrm{NH}_{4}-\mathrm{N}$ removal at a drinking water supply system in Kathmandu Valley, Nepal. J. Environ. Sci. Health Part A 2012, 47, 734-743. [CrossRef]

33. APHA/AWWA/WEF. Standard Methods for the Examination of Water and Wastewater, 20th ed.; Clesceri, L.S., Greenberg, A.E., Eaton, A.D., Eds.; American Public Health Association, American Water Works Association, Water Environment Federation: Washington, DC, USA, 1998.

34. Bru, D.; Martin-Laurent, F.; Philippot, L. Quantification of the detrimental effect of a single primer-template mismatch by real-time PCR using the 16S rRNA gene as an example. Appl. Environ. Microbiol. 2008, 74, 1660-1663. [CrossRef]

35. Dionisi, H.M.; Layton, A.C.; Harms, G.; Gregory, I.R.; Robinson, K.G.; Sayler, G.S. Quantification of Nitrosomonas oligotropha-like ammonia-oxidizing bacteria and Nitrospira spp. from full-scale wastewater treatment plants by competitive PCR. Appl. Environ. Microbiol. 2002, 68, 245-253. [CrossRef]

36. Poly, F.; Wertz, S.; Brothier, E.; Degrange, V. First exploration of Nitrobacter diversity in soils by a PCR cloning-sequencing approach targeting functional gene nxrA. FEMS Microbiol. Ecol. 2008, 63, 132-140. [CrossRef]

37. Lopez-Gutierrez, J.C.; Henry, S.; Hallet, S.; Martin-Laurent, F.; Catroux, G.; Philippot, L. Quantification of a novel group of nitrate-reducing bacteria in the environment by real-time PCR. J. Microbiol. Methods 2004, 57, 399-407. [CrossRef] [PubMed]

38. Yan, T.; Fields, M.W.; Wu, L.; Zu, Y.; Tiedje, J.M.; Zhou, J. Molecular diversity and characterization of nitrite reductase gene fragments (nirK and nirS) from nitrate- and uranium-contaminated groundwater. Environ. Microbiol. 2003, 5, 13-24. [CrossRef] [PubMed]

39. Throback, I.N.; Enwall, K.; Jarvis, A.; Hallin, S. Reassessing PCR primers targeting nirS, nirK and nosZ genes for community surveys of denitrifying bacteria with DGGE. FEMS Microbiol. Ecol. 2004, 49, 401-417. [CrossRef] [PubMed]

40. Scala, D.J.; Kerkhof, L.J. Nitrous oxide reductase (nosZ) gene-specific PCR primers for detection of denitrifiers and three nosZ genes from marine sediments. FEMS Microbiol. Lett. 1998, 162, 61-68. [CrossRef] [PubMed]

41. Sickle-A Windowed Adaptive Trimming Tool for FASTQ Files Using Quality. Available online: https: //github.com/najoshi/sickle (accessed on 2 March 2020). 
42. Fastx-Toolkit. Available online: http://hannonlab.cshl.edu/fastx_toolkit/download.html (accessed on 2 March 2020).

43. Flash. Available online: https://sourceforge.net/projects/flashpage/files/ (accessed on 2 March 2020).

44. Usearch. Available online: https://www.drive5.com/usearch/ (accessed on 2 March 2020).

45. Lin, Y.F.; Jing, S.R.; Wang, T.W.; Lee, D.Y. Effects of macrophytes and external carbon sources on nitrate removal from groundwater in constructed wetlands. Environ. Pollut. 2002, 119, 413-420. [CrossRef]

46. Rahmani, A.R.; Samadi, M.T.; Ehsani, H.R. Investigation of clinoptilolite natural zeolite regeneration by air stripping followed by ion exchange for removal of ammonium from aqueous solutions. Iran. J. Environ. Health Sci. Eng. 2009, 6, 167-172.

47. Deng, Q.; Elbeshbishy, E.; Lee, H.S. Simultaneous regeneration of exhausted zeolite and nitrogen recovery using an air stripping method at alkaline pH. Water Qual. Res. J. Can. 2016, 51, 321-330. [CrossRef]

48. Lei, X.; Li, M.; Zhang, Z.; Feng, C.; Bai, W.; Sugiura, N. Electrochemical regeneration of zeolites and the removal of ammonia. J. Hazard. Mater. 2009, 169, 746-750. [CrossRef]

49. Lahav, O.; Green, M. Bioregenerated ion-exchange process: The effect of the biofilm on the ion-exchange capacity and kinetics. Water $S A$ 2000, 26, 51-57.

50. Rahmani, A.R.; Mahvi, A.H. Use of Ion Exchange for Removal of Ammonium: A Biological Regeneration of Zeolite. Glob. NEST J. 2006, 8, 146-150. [CrossRef]

51. Sun, G.; Zhao, Y.; Allen, S. Enhanced removal of organic matter and ammoniacal-nitrogen in a column experiment of tidal flow constructed wetland system. J. Biotechnol. 2005, 115, 189-197. [CrossRef] [PubMed]

52. Wu, S.; Zhang, D.; Austin, D.; Dong, R.; Pang, C. Evaluation of a lab-scale tidal flow constructed wetland performance: Oxygen transfer capacity, organic matter and ammonium removal. Ecol. Eng. 2011, 37, 1789-1795. [CrossRef]

53. Li, C.; Wu, S.; Dong, R. Dynamics of organic matter, nitrogen and phosphorus removal and their interactions in a tidal operated constructed wetland. J. Environ. Manag. 2015, 151, 310-316. [CrossRef] [PubMed]

54. Chang, Y.; Wu, S.; Zhang, T.; Mazur, R.; Pang, C.; Dong, R. Dynamics of nitrogen transformation depending on different operational strategies in laboratory-scale tidal flow constructed wetlands. Sci. Total Environ. 2014, 487, 49-56. [CrossRef] [PubMed]

55. Li, J.; Hu, Z.; Li, F.; Fan, J.; Zhang, J.; Li, F.; Hu, H. Effect of oxygen supply strategy on nitrogen removal of biochar-based vertical subsurface flow constructed wetland: Intermittent aeration and tidal flow. Chemosphere 2019, 223, 366-374. [CrossRef]

56. Liu, C.; Li, X.; Yang, Y.; Fan, X.; Tan, X.; Yin, W.; Liu, Y.; Zhou, Z. Double-layer substrate of shale ceramsite and active alumina tidal flow constructed wetland enhanced nitrogen removal from decentralized domestic sewage. Sci. Total Environ. 2020, 703, 135629. [CrossRef]

57. Münch, C.; Kuschk, P.; Röske, I. Root stimulated nitrogen removal: Only a local effect or important for water treatment? Water Sci. Technol. 2005, 51, 185-192. [CrossRef]

58. Zhu, T.; Sikora, F.J. Ammonium and nitrate removal in vegetated and unvegetated gravel bed microcosm wetlands. Water Sci. Technol. 1995, 32, 219-228. [CrossRef]

59. Hu, Y.; He, F.; Ma, L.; Zhang, Y.; Wu, Z. Microbial nitrogen removal pathways in integrated vertical-flow constructed wetland systems. Bioresour. Technol. 2016, 207, 339-345. [CrossRef]

60. Toyama, T.; Nishimura, Y.; Ogata, Y.; Sei, K.; Mori, K.; Ike, M. Effects of planting Phragmites australis on nitrogen removal, microbial nitrogen cycling, and abundance of ammonia-oxidizing and denitrifying microorganisms in sediments. Environ. Technol. 2015, 37, 478-485. [CrossRef]

61. Wang, Q.; Xie, H.; Ngo, H.H.; Guo, W.; Zhang, J.; Liu, C.; Liang, S.; Hu, Z.; Yang, Z.; Zhao, C. Microbial abundance and community in subsurface flow constructed wetland microcosms: Role of plant presence. Environ. Sci. Pollut. Res. 2016, 23, 4036-4045. [CrossRef] [PubMed]

62. Han, Z.; Dong, J.; Shen, Z.; Mou, R.; Zhou, Y.; Chen, X.; Fu, X.; Yang, C. Nitrogen removal of anaerobically digested swine wastewater by pilot-scale tidal flow constructed wetland based on in-situ biological regeneration of zeolite. Chemosphere 2019, 217, 364-373. [CrossRef] [PubMed]

63. Chen, Y.; Wen, Y.; Tang, Z.; Huang, J.; Zhou, Q.; Vymazal, J. Effects of plant biomass on bacterial community structure in constructed wetlands used for tertiary wastewater treatment. Ecol. Eng. 2015, 84, 38-45. [CrossRef]

64. Rich, J.J.; Heichen, R.S.; Bottomley, P.J.; Cromack, K.; Myrold, D.D. Community composition and functioning of denitrifying bacteria from adjacent meadow and forest soils. Appl. Environ. Microbiol. 2003, 69, 5974-5982. [CrossRef] [PubMed] 
65. Tan, X.; Yang, Y.; Li, X.; Zhou, Z.; Liu, C.; Liu, Y.; Yin, W.; Fan, X. Intensified nitrogen removal by heterotrophic nitrification aerobic denitrification bacteria in two pilot-scale tidal flow constructed wetlands: Influence of influent $\mathrm{C} / \mathrm{N}$ ratios and tidal strategies. Bioresour. Technol. 2020, 302, 122803. [CrossRef]

66. Chen, Z.; Vymazal, J.; Kuschk, P. Effects of tidal operation on pilot-scale horizontal subsurface flow constructed wetland treating sulfate rich wastewater contaminated by chlorinated hydrocarbons. Environ. Sci. Pollut. Res. 2017, 24, 1042-1050. [CrossRef]

(C) 2020 by the authors. Licensee MDPI, Basel, Switzerland. This article is an open access article distributed under the terms and conditions of the Creative Commons Attribution (CC BY) license (http://creativecommons.org/licenses/by/4.0/). 